\title{
INSIGHT INTO PARTICIPATION OF GENERATING SOURCES IN THE ENERGY SUPPLY TO LOADS
}

\author{
J. Survilo, V. Strelkovs \\ Riga Technical University, the Institute of Power Engineering, \\ 1 Kronvalda Blvd., Riga LV-1010, LATVIA
}

Under the market economy conditions every producer should know the proportion of electrical energy to be delivered to a concrete load and the energy losses that arise at delivery. Any network is characterised by such parameters as loads, generated power, power from slack buses, flows in its branches, etc., which can be determined by computer programs, e.g. Mustang or Power World. However, these programs do not compute the share of a particular power plant (PP) in supplying a particular load, since the PPs can be involved in the load delivery in different proportions, without changing the input information on the generated power, loads and branch flows. Therefore, solution of this problem is not purely technical, and many alternative solutions are proposed, the most important among them being based on the principle of proportionality. This principle is in conflict with the notion of the injection node. If the share of a PP in the load coverage is not known, the flow of this plant in the network branches is also unknown. In the paper, it is proposed to take into account the admittance from a PP to the load, calculating the load share to be covered by this plant. The current from a PP to the load should be calculated proportionally to the admittance of the path to load, after which the admittance of the involved power line attached to a PP is determined. Such admittances take into account not only impedances of these lines but also the currents flowing from other PPs and can be calculated when in the lines not only collinear but also differing in phase currents flow; in the latter case the angle between the currents is accounted for. In such a manner, the load coverage quotient is determined that shows the load coverage to be shared by a given PP. All coverage quotients known, the address coefficients for all PPs can be calculated. This method allows more realistic calculation of the flows from PPs in a particular power line. The losses of a given PP are found by well-known formulas, assuming that a definite proportion of the phase conductor cross-section of a given line belongs to a given PP. This proportion is found taking into account all the flows in this line.

Key words: charges for electricity loss, electricity consumer, load flow, loss allocation, power losses, power plant (PP).

\section{INTRODUCTION}

To determine expenses of electricity supply, the problem should be considered from two sides: 1) to decide on the share of a given consumer's load for each power plant (PP) which generates to the network; 2) to come to agreement about sharing the power losses between suppliers that use the same power line.

A vast number of publications indicate that these questions are paid great attention under the present-day market economy conditions. This shows not only the topicality of the problem but also testifies that it is being solved in various ways. All the methods employ the branch power flow values that describe real situations in the grid and are calculated using computer programs. 
At the same time, these programs do not solve (and are unable to do it without additional assumptions) the question as to participation of each generator in covering the load of each particular consumer. Now, three basic approaches to solving the problem can be defined [1]: 1) Rudnick's method [2], which rests on the preliminarily determined sharing factors; 2) Bialek's method [3], which is based on the proportionality principle [4]; 3) Kirschen's method [5], which uses a particular procedure of the load current calculation. Apart from those, a comparative method for load currents exists [6] where the load flows from different generators are calculated separately; also, modifications of these methods are proposed, e.g. [7]. The diversity of solutions manifests itself in various assumptions that are needed to solve such tasks when the electrical circuit laws fail. As a plausible axiom the proportionality principle can be considered. This principle is employed in several methods, e.g. in [8] aimed at solving the first part of the originally stated task. At the same time, this principle is unsuitable for determination of a generator's share in the load coverage, since it contradicts the notion of the injection node. For example, when currents of two PPs merge in one power line with a load at its end and the rest of the common current is then flowing further, any portion of the power produced by these plants can be allocated for this load, and the circuit laws will be satisfied provided the sum of power portions is equal to the supplied load. Here an additional assumption is required. The proportionality principle not always can be applied, e.g. in the cases when a generator is situated near the load. The problem of loss allocation to PPs is considered in detail in [9], however the solution proposed there is far from true and encourages one to search for a better solution.

Below, an alternative solution of this problem is proposed.

\section{REVIEW OF ADDRESS MATRIX}

According to [8], to determine the share of the $n$-th generator's current flowing to load $m$ the address coefficient $\alpha_{m n}$ is to be found as shown in Fig. 1. In this figure, power plants $G 1, G 2$ with powers $P_{G 1}, P_{G 2}$, are connected to nodes 1,2 , respectively; two loads $P_{L 3}, P_{L 4}$ are connected by power lines to nodes 3,4 respectively. Plant $G 1$ is at a distance of $30 \mathrm{~km}$ from node 1 , and plant $G 2$ - at $20 \mathrm{~km}$ from node 2 . The branch currents are computed in the stationary mode. Plant $G 1$ delivers its active power $P_{1}$ to node 3 , and $P_{1}{ }^{\prime}$ and $P_{1}{ }^{\prime \prime}-$ via two other branches - to other nodes. Plant $G 2$ unloads its power in the same way. The address coefficient $\alpha_{31}$, which determines the portion $P_{L 3 G 1}$ of plant $G 1$ power delivered to load $P_{3}$, is:

$$
\alpha_{31}=\bar{P}_{L 3} \bar{P}_{1},
$$

where $\bar{P}_{L 3}$ is the relative load;

$\bar{P}_{1}$ is the relative branch flow, which are determined as

$$
\bar{P}_{L 3}=\frac{P_{L 3}}{P_{L 3}+P_{3}} ; \quad \bar{P}_{1}=\frac{P_{1}}{P_{1}+P_{1}^{\prime}+P_{1}^{\prime \prime}}=\frac{P_{1}}{P_{G 1}} .
$$

Plant $G 1$ delivers to load $P_{L 3}$ the following power: 


$$
P_{L 3 G 1}=\alpha_{31} P_{G 1}=\frac{P_{L 3}}{P_{L 3}+P_{3}} \frac{P_{1}}{P_{G 1}} P_{G 1}=\frac{P_{L 3} P_{1}}{P_{L 3}+P_{3}} .
$$
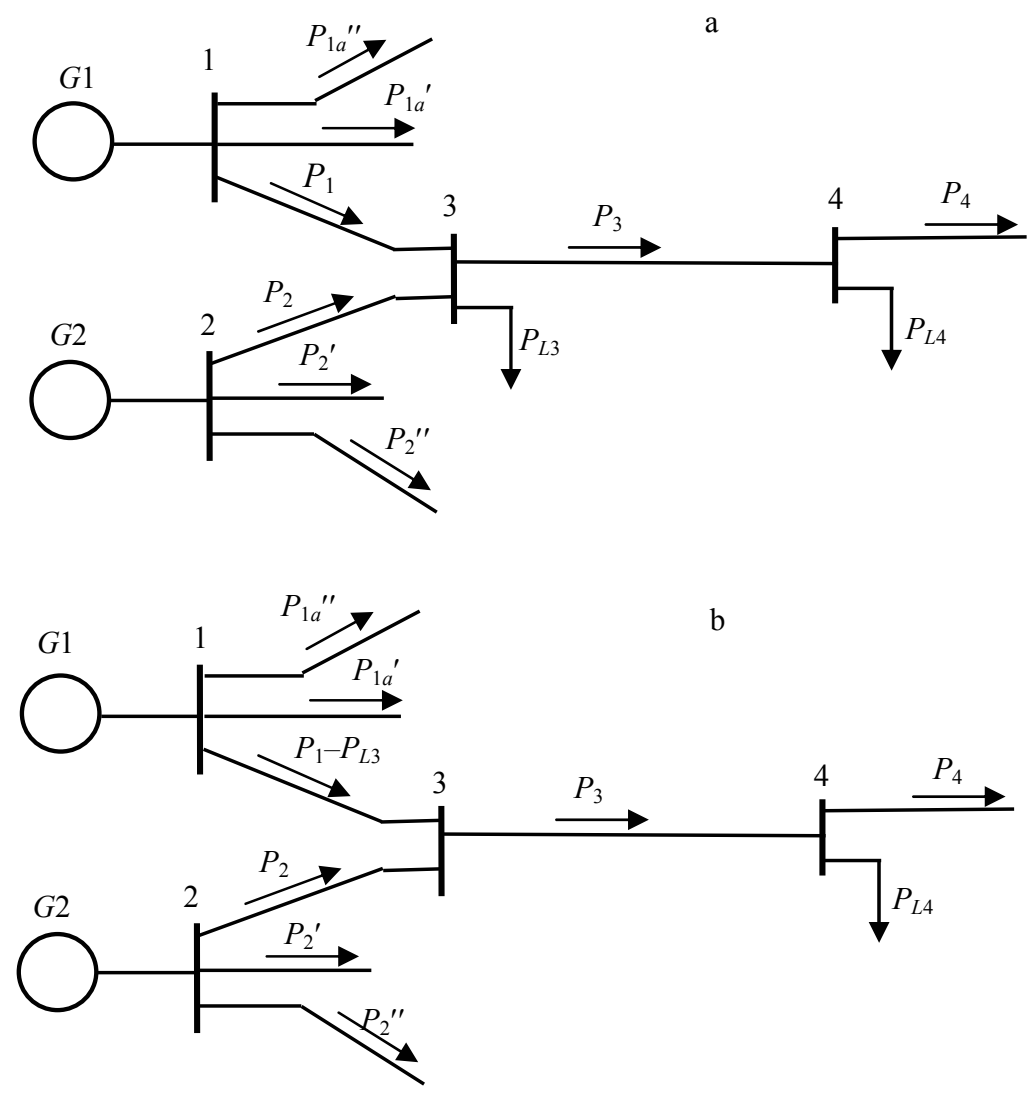

Fig. 1. Network fragment with two power plants $G 1$ and $G 2: a$-plant G1 is at a distance of $30 \mathrm{~km}$ from load $P_{L 3} ; b$-plant $G 1$ is close to load $P_{L 3} ;$ plant $G 2$ remains at $30 \mathrm{~km}$ from node 2.

Analogically, plant $G 2$ delivers to load $P_{L 3}$ the power:

$$
P_{L 3 G 2}=\alpha_{32} P_{G 2}=\frac{P_{L 3}}{P_{L 3}+P_{3}} \frac{P_{2}}{P_{G 2}} P_{G 2}=\frac{P_{L 3} P_{2}}{P_{L 3}+P_{3}} \text {. }
$$

One can see that load $P_{L 3}$ receives power from plants $G 1$ and $G 2$ proportionally to flows $P_{1}$ and $P_{2}$ in respective branches; besides:

$$
P_{1}+P_{2}=P_{L 3}+P_{3} .
$$

For node 4 we obtain:

$$
\begin{aligned}
P_{L 4 G 1}= & \alpha_{41} P_{G 1}=\bar{P}_{L 4} \bar{P}_{1} \bar{P}_{3} P_{G 1}=\frac{P_{L 4}}{P_{L 4}+P_{4}} \frac{P_{1}}{P_{G 1}} \frac{P_{3}}{P_{L 3}+P_{3}} P_{G 1}= \\
= & \frac{P_{L 4} P_{1} P_{3}}{\left(P_{L 4}+P_{4}\right)\left(P_{L 3}+P_{3}\right)}
\end{aligned}
$$




$$
\begin{aligned}
P_{L 4 G 2}= & \alpha_{42} P_{G 2}=\bar{P}_{L 4} \bar{P}_{2} \bar{P}_{3} P_{G 2}=\frac{P_{L 4}}{P_{L 4}+P_{4}} \frac{P_{2}}{P_{G 2}} \frac{P_{3}}{P_{L 3}+P_{3}} P_{G 2}= \\
& =\frac{P_{L 4} P_{2} P_{3}}{\left(P_{L 4}+P_{4}\right)\left(P_{L 3}+P_{3}\right)},
\end{aligned}
$$

where relative current $\bar{P}_{3}$ of branch $3-4$ is

$$
\bar{P}_{3}=\frac{P_{3}}{P_{L 3}+P_{3}}
$$

Hence to load $P_{L 4}$ the current is flowing that is proportional to quantities $P_{1}$ and $P_{2}$. If we neglect the network losses, then

$$
P_{L 3 G 1}+P_{L 3 G 2}=P_{L 3} ; \quad P_{L 4 G 1}+P_{L 4 G 2}=P_{L 4} .
$$

At a shorter distance of plant $G 1$ to load $P_{L 3}$ (to node 3), e.g. $10 \mathrm{~km}$, flows $P_{1}$ and $P_{2}$ would remain the same since the active power is scheduled; hence $P_{L 3 G 1}$, $P_{L 4 G 1}, P_{L 3 G 2}, P_{L 4 G 2}$ are still determined by Eqs. (3)-(7), i.e. they remain the same.

The same will happen if the distance is reduced to $1 ; \ldots ; 0.5 ; 0.15 \mathrm{~km}$. But when the distance shortens to $100 \mathrm{~m}$, node 3 abruptly converts to an injection node [8], which means that plant $G 1$ itself supplies load $P_{L 3}$. The diagram of Fig. $1 a$ directly transforms to that of Fig. $1 b$. The load disappears from node 3 and the flow of branch 1-3 will be:

$$
P_{1 i n}=P_{1}-P_{L 3} .
$$

Hereto, from Fig. $1 b$ we can see that expression (5) is valid. For the coefficients determined above the following holds: $\bar{P}_{L 3} ; \bar{P}_{1} ; P_{L 3 G 1} ; \alpha_{31} ; \alpha_{32}$ are not actual anymore. Instead, a new coefficient appears as

$$
\bar{P}_{1 \text { in }}=\frac{P_{1 \text { in }}}{P_{1 \text { in }}+P_{1}^{\prime}+P_{1}{ }^{\prime \prime}}=\frac{P_{1 i n}}{P_{G 1}{ }^{\prime}} .
$$

Coefficients $\bar{P}_{L 4} ; \bar{P}_{2}$ (see (7)) do not change. Coefficient $\bar{P}_{3}$ is:

$$
\bar{P}_{3}=1,
$$

hence load $P_{L 3}$ will not appear anymore.

Plants $G 1$ and $G 2$ deliver to load $P_{L 4}$ the power:

$$
P_{L 4,1 \text { in }}=\vec{P}_{L 4} \bar{P}_{1 i n} P_{1 i n} ; \quad P_{L 4 G 2}=\bar{P}_{L 4} \bar{P}_{2} P_{G 2} .
$$

The sum of $P_{L 4,1 i n}$ and $P_{L 4 G 2}$ is equal to the load capacity $P_{L 4}$. It can be checked applying the above written formulas and taking into account that $P_{L 4}+P_{4}=$ $P_{1 \text { in }}+P_{2}$.

Loads $P_{L 3}$ and $P_{L 4}$ remaining unchanged, the shares of power plants in coverage of these loads change abruptly. Load $P_{L 3}$ disappears from node 3, while from plant $G 1$ to node 3 the power $P_{1 \text { in }}$ is flowing that is less than the previous 
value of $P_{L 3}$. Node 1 receives load $P_{L 3}$ and turns into an injection node and actually merges with node 3 , since the impedance between these nodes can be considered zero. This means that the losses to be paid for by PPs have suddenly changed. The owner of a plant is interested in its being considered the injection node; the owner of another plant is interested in the opposite, because he should pay less for power losses. As usual, a compromise should be sought for. We can see that the load distribution on the proportionality principle is voluntary, and in no way is based on the circuit laws. If, instead of plant $G 1$, there would be a system of unlimited power, it just would "eat" load $P_{L 3}$. At such a system's gradually moving away from load 3, at some distance (which is difficult to define) the load distribution would at once be considered proportional. In order that such a controversy could not appear, the distribution of power to the loads should somehow be linked to the network parameters. The questions as to how it can be done and whether we can use the network parameters at determination of the address coefficients, involving to an extent the laws of electro-technical engineering, will be considered below.

\section{POWER ALLOCATION TO THE FIRST LOAD}

First, we will consider a simple case, when power plant $G$ (Fig. 2) delivers electricity to load $L$ by the line with impedance $\dot{Z}_{G L}$, besides, electricity is delivered to load $L$ also from system $S$ by line with impedance $\dot{Z}_{S L}$; the system is much more distant from load $L\left(\dot{Z}_{S L}>>\dot{Z}_{G L}\right)$. The total power of two sources is

$$
P_{S}+P_{G}>P_{L}
$$
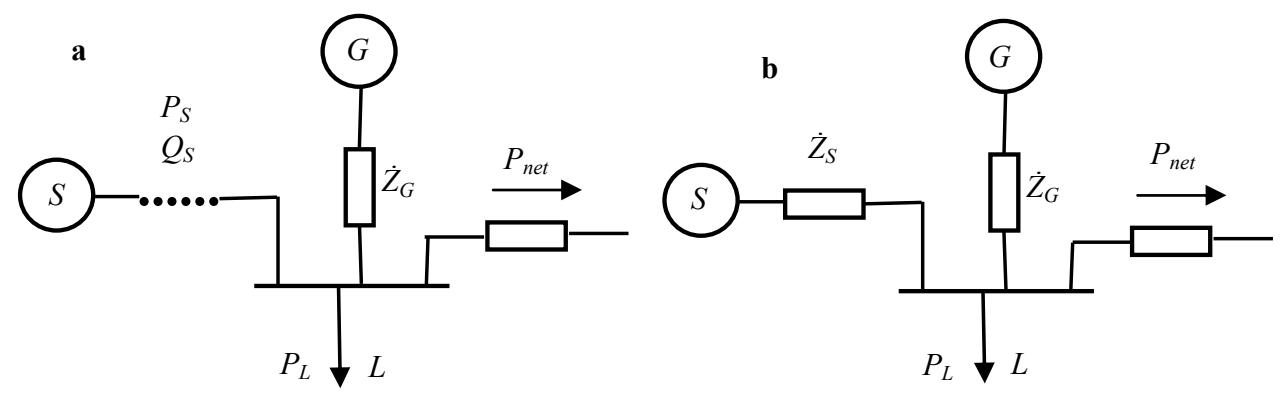

Fig. 2. Electricity supply to load $L$ from two sources:

$a-\dot{Z}_{S L}>>\dot{Z}_{G L}$ and $P_{S}, Q_{S} \approx$ const; b- $\dot{Z}_{S L}$ is commensurable with $\dot{Z}_{G L}$.

The difference is put out to the network:

$$
P_{S}+P_{G}-P_{L}=P_{n e t} .
$$

Since the system is located far, we can consider that it sends unchanged flow, i.e. invariable current $\dot{I}_{S}$, while the current flowing from the PP is:

$$
\dot{I}_{G}=\frac{\dot{U}_{G}-\dot{U}_{L}}{\dot{Z}_{G L}},
$$

where $\dot{U}_{G}$ and $\dot{U}_{L}$ are the voltages of PP and load, respectively. 
Let us suppose that the reactive power of the load has increased and, consequently, the load voltage decreased by $\Delta \dot{U}$. The plant's generators maintain a constant voltage on the plant buses, hence the current from the PP will be:

$$
\dot{I}_{G}{ }^{\prime}=\frac{\dot{U}_{G}-\left(\dot{U}_{L}-\Delta \dot{U}\right)}{\dot{Z}_{G L}}=\dot{I}_{G}+\frac{\Delta \dot{U}}{\dot{Z}_{G L}}=\dot{I}_{G}+\Delta I_{G r} .
$$

The voltage change will cause the power plant to raise its reactive current by $\Delta I_{G r}$.

Now let us increase the active load, the reactive load remaining unchanged. Neither the system nor the plant will change their generation of active power, since for the system this change is too small, and the PP does not receive a signal to change the energy supply while the primary regulation as of yet does not act. Plant generators sense the voltage change on its buses and increase their reactive power; as concerns the system, it does not sense anything, and hence no changes occur. As far as there is increase in the active load but the generated power has not changed, more of the active power will flow to the load and less to the network. This means that $\dot{I}_{\text {net }}$ decreases. However it is unclear what power source would be ready to increase the active current in the load.

Let us assume that the load has dropped to zero. The voltage on load buses will rise, which is felt by the PP. Since the plant generators put out the same active power, they will need to decrease excitation - possibly to such a level that there will be necessary to receive reactive power from the network.

Hence, at active load changing the power plant will change its reactive power. Since the system is far, no changes in its active power occur due to frequency being constant, and the reactive current remains the same. The conclusion is therefore that the $\mathrm{PP}$ alone changes its reactive power.

When the system is not located so far as compared with the PP, then, at the voltage on the plant's and system's buses being constant, the voltage change on the load buses will be covered by reactive power changes both from the plant and the system, with participation of these two sources proportional only to admittances $\dot{Y}_{S L}$ and $\dot{Y}_{G L}$, respectively.

We will now consider two circuits, before and after changes. In the former case:

$$
\dot{I}_{G}=\left(\dot{U}_{G}-\dot{U}_{L}\right) \dot{Y}_{G L} ; \quad \dot{I}_{S}=\left(\dot{U}_{S}-\dot{U}_{L}\right) \dot{Y}_{S L}
$$

After changes:

$$
\begin{aligned}
& \dot{I}_{G}+\Delta \dot{I}_{G r}=\left[\dot{U}_{G}-(\dot{U}-\Delta \dot{U})\right] \dot{Y}_{G L} \\
& \dot{I}_{S}+\Delta \dot{I}_{S r}=\left[\dot{U}_{S}-(\dot{U}-\Delta \dot{U})\right] \dot{Y}_{S L}
\end{aligned}
$$

The share of each source in covering the load augment is:

$$
\Delta \dot{I}_{G r}=\Delta \dot{U} \dot{Y}_{G L} ; \quad \Delta \dot{I}_{S r}=\Delta \dot{U} \dot{Y}_{S L}
$$

The admittance can be found from (18) as

$$
\dot{Y}_{G L}=\frac{\dot{I}_{G}}{\dot{U}_{G}-\dot{U}_{L}} \text {. }
$$


Substituting (21) into (20), we have:

$$
\Delta \dot{I}_{G r}=\Delta \dot{U} \frac{\dot{I}_{G}}{\dot{U}_{G}-\dot{U}_{L}} ; \quad \Delta \dot{I}_{S r}=\Delta \dot{U} \frac{\dot{I}_{S}}{\dot{U}_{S}-\dot{U}_{L}} .
$$

From (22) we can see that to cover the reactive load change the source current value cannot be used, since changes in the coverage depend not only on the current but also on the source voltage. Using admittance, the load changes are estimated uniquely. Now we can state that each source participates in the load change coverage proportionally to its admittance.

In the case when the energy from two sources merges at some node without load, the reactive power change proceeds in the same way according to Eq. (22); in this case at the former load the voltage change $\Delta \dot{U}_{0}$ will be greater, and the reactive currents can be determined by formulas (20) with $\Delta \dot{U}_{0}$ in place of $\Delta \dot{U}$. Hence, two sources participate proportionally to their admittances, both in covering the reactive current change and the load currents.

The active power is shared between the load and the network. We will assume that in Fig. $1 a$ only the active load increases, while the reactive load remains the same. The voltage across the load will decrease (possibly to a lesser extent), hence it will decrease on the plant buses as well; to raise the latter, it is necessary to increase the reactive current flowing in the network, which will lead to decrease in the active current (owing to the increase in reactive current) from the power plant side. Therefore, instead of active current the PP will send reactive current to the network, which means that the plant will redistribute the shares of active current to the load and the network in favour of the former. From Fig. $2 b$ it follows that this source more decreases the network's share of the active current that has greater admittance to the load. The conclusion is: the distribution of active current has the same character as that for reactive current, i.e. is proportional to the admittance from the energy source to the load.

Relying on the said above, the current formulas for $G_{1} ; G_{2} ; \ldots G_{N}$ sources that feed load $L$ along separate lines with admittances $\dot{Y}_{G 1 L} ; \dot{Y}_{G 2 L} ; \ldots \dot{Y}_{G N L}$ will appear as

$$
\dot{I}_{G 1 L}=\Delta \dot{U}_{L} \dot{Y}_{G 1 L} ; \quad \dot{I}_{G 2 L}=\Delta \dot{U}_{L} \dot{Y}_{G 2 L} ; \quad \dot{I}_{G N L}=\Delta \dot{U}_{L} \dot{Y}_{G N L} .
$$

The proposed approach ensures the continuity of current redistribution to the load. Deducing from (23), the sum of current changes is:

$$
\dot{I}_{L}=\sum_{i=1}^{N} \dot{I}_{G i L}=\Delta \dot{U}_{L} \sum_{i=1}^{N} \dot{Y}_{i L}
$$

A power plant participates in the load coverage according to its admittance to this load weighted against the summary admittance to it of all plants involved. The ratio of a particular PP's admittance to the summary admittances of all the PPs shows what share of load is covered by this plant. In order that this ratio is not a complex number, the modules of implied quantities are used. Now each $n$-th plant participates in load $L$ coverage corresponding to its quotient $\beta_{n L}$, i.e.: 


$$
\beta_{n L}=\frac{I_{G n L}}{I_{L}}=\frac{Y_{G n L}}{\sum_{i=1}^{N} Y_{G i L}} .
$$

If the energy is supplied by multiple paths, in the numerator of expression (25) the summary admittance $Y_{G n L \Sigma}$ appears:

$$
\beta_{n L}=\frac{Y_{G n L \Sigma}}{\sum_{i=1}^{N} Y_{G i L}} .
$$

This means that the $n$-th plant's share sent to load $L$ according to quotient $\beta_{n L}$ is

$$
P_{G n L}=\beta_{n L} P_{L},
$$

whereas the share of load $L$ covered by the $n$-th plant should not exceed the current flowing in the direction towards this load. From Fig. $2 a$ we have $\beta_{G L} \approx 1 ; \beta_{S L} \approx 0$ since $Y_{G L}>>Y_{S L}$. This means that the PP sends to load $L$ its maximum possible current and the rest - to the network. As soon as the plant moves electrically away from load $\left(\beta_{G L}<1\right)$, the other source (the system) also supplies the load.

If $N$ plants supply $M$ loads, the coverage quotient of the $m$-th load is determined as

$$
\beta_{n m}=\frac{Y_{G n L m}}{\sum_{i=1}^{N} Y_{G i L m}}=\frac{P_{G n L m}}{P_{L m}} .
$$

The capacity of each power plant $\boldsymbol{P}_{\boldsymbol{G}}$ why bold?is expressed by loads $\boldsymbol{P}_{\boldsymbol{L}}$ and coverage quotients $\boldsymbol{B}_{G L}$ :

$$
\boldsymbol{P}_{G}=\boldsymbol{B}_{G L} \boldsymbol{P}_{L}
$$

where

$$
\boldsymbol{B}_{G L}=\left[\beta_{n m}\right]_{N M} .
$$

Therewith, the flow to load $L_{m}$ must not exceed the plant's flow $P_{b G n L m}$ in the direction of this load:

$$
P_{G n L m} \leq P_{b G n L m},
$$

where $P_{b G n L m}$ is the known (calculated) branch current flowing out of the $n$-th plant in the direction of load $L_{m}$.

So far the power of PP distribution to load has been proposed when there is no common path to the load. However, the network being a complicated system, such a simple case adds but little to solving the problem. A more complicated network will be considered in Ch. 4 .

We will turn now to the second part of the originally stated problem: what losses are to be allocated to each power plant that sends electricity by a common line. The notion of attached impedances (resistances) will be used. 


\section{ATTACHED IMPEDANCES AND NATURAL \\ ALLOCATION OF LOSSES TO POWER PLANTS}

We shall consider the cases when both flows converge in one line (Fig. 3). First, the case with the same direction of both currents will be analyzed. Current $I_{1}$ flows from the first source, and current $I_{2}-$ from the second. Current $I$ in branch $\mathrm{M}_{1}-\mathrm{M}_{2}$ is the sum of both currents (Fig. 3):

$$
I=I_{1}+I_{2} \text {. }
$$

The voltage drop across branch $\mathrm{M}_{1}-\mathrm{M}_{2}$ is

$$
\Delta \dot{U}=\dot{Z} I=\Delta U^{\prime}+j \Delta U^{\prime \prime}=R I+j X I,
$$

where $\dot{Z}, R$ and $X$ are the impedance, resistance and reactance, respectively.

In Fig. $3 b$, the conductor of $\mathrm{M}_{1}-\mathrm{M}_{2}$ branch is split into two wires with currents $I_{1}$ and $I_{2}$, respectively. Both wires have therefore common endpoints $\mathrm{M}_{1}$ and $\mathrm{M}_{2}$, and lie near each other. It is obvious that after splitting the voltage drop between $\mathrm{M}_{1}$ and $\mathrm{M}_{2}$ is to remain unchanged, i.e. $\Delta \dot{U}$; this means that

$$
\begin{gathered}
\Delta U_{1}^{\prime}+j \Delta U^{\prime \prime}=\Delta U_{2}^{\prime}+j \Delta U^{\prime \prime}=R_{1} I_{1}+j X I=R_{2} I_{2}+j X I= \\
=R I+j X I=\Delta U^{\prime}+j \Delta U^{\prime \prime}=\Delta \dot{U} .
\end{gathered} .
$$

a
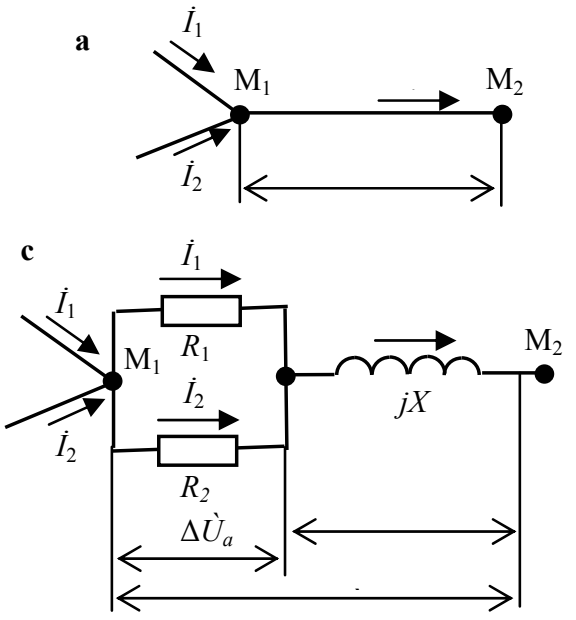

b
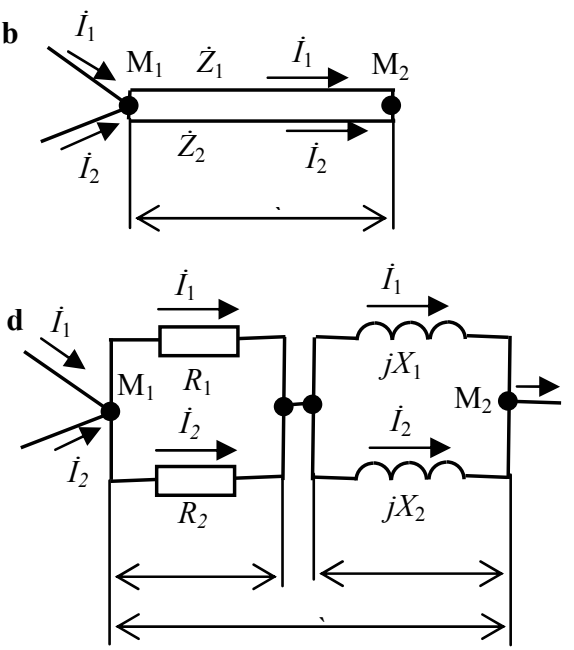

Fig. 3. Power transfer from two sources via the same line: $a$ - original scheme; $b$ - equivalent circuit with a bifurcated (imaginary) common line ; $c$ - circuit with a split conductor for active resistance; $d$-circuit with a split conductor for active resistance and reactance.

First, we will decompose the conductor into two wires considering the active resistance only, since this can be done in terms of physics: instead of a single conductor we arrange two wires with the total cross-section area being equal to that of the original conductor. We cannot assign the imaginary component of voltage drop to separate wire since one wire cannot be separated from the other; the reactance remains common and carries total current $\dot{I}$ (Fig. 3c). From (34) follows 


$$
\Delta U_{1}^{\prime}=\Delta U_{2}^{\prime}=R_{1} I_{1}=R_{2} I_{2}=R I=\Delta U^{\prime},
$$

hence the condition which emerges from Fig. $3 c$, namely:

$$
\Delta U_{1}^{\prime}=\Delta U_{2}^{\prime}=\Delta U^{\prime}
$$

is met. From (32) and (35) we obtain:

$$
R_{1}=R\left(1+\frac{I_{2}}{I_{1}}\right) ; \quad R_{2}=R\left(1+\frac{I_{1}}{I_{2}}\right) .
$$

The common resistance of parallel wires is:

$$
\frac{R_{1} R_{2}}{R_{1}+R_{2}}=\frac{R\left(1+\frac{I_{2}}{I_{1}}\right) R\left(1+\frac{I_{1}}{I_{2}}\right)}{R\left(1+\frac{I_{2}}{I_{1}}\right)+R\left(1+\frac{I_{1}}{I_{2}}\right)}=R .
$$

The expression shows that the sum of the wires' cross-section areas is equal to the cross-section area of the original conductor. Concerning the losses, in the first and the second wire they are:

$$
\begin{aligned}
& \Delta P_{1}=R_{1} I_{1}^{2}=R\left(1+\frac{I_{2}}{I_{1}}\right) I_{1}^{2}=R I_{1}^{2}+R I_{1} I_{2} ; \\
& \Delta P_{2}=R_{2} I_{2}^{2}=R\left(1+\frac{I_{1}}{I_{2}}\right) I_{2}^{2}=R I_{2}^{2}+R I_{2} I_{1} .
\end{aligned}
$$

Their sum is:

$$
\Delta P_{\Sigma}=\Delta P_{1}+\Delta P_{2}=R I_{1}{ }^{2}+2 R I_{1} I_{2}+R I_{2}{ }^{2},
$$

which coincides with the losses $\Delta P$ resulting from the summary current $I=\left(I_{1}+I_{2}\right)$ that flows in the original conductor with resistance $R$ :

$$
\Delta P=R I^{2}=R\left(I_{1}+I_{2}\right)^{2}=R I_{1}^{2}+2 R I_{1} I_{2}+R I_{2}^{2} .
$$

We thus obtain the proof that such an allocation of losses in accordance with currents is legitimate. The share of losses for which a given supplier pays will be:

$$
\eta_{1}=\frac{\Delta P_{1}}{\Delta P}=\frac{I_{1}^{2}+I_{1} I_{2}}{\left(I_{1}+I_{2}\right)^{2}} ; \quad \eta_{2}=\frac{\Delta P_{2}}{\Delta P}=\frac{I_{2}^{2}+I_{1} I_{2}}{\left(I_{1}+I_{2}\right)^{2}} .
$$

If the directions of currents do not coincide, these can be expressed as

$$
\dot{I}_{1}=I_{1} e^{j \alpha_{1}} ; \quad \dot{I}_{2}=I_{2} e^{j \alpha_{2}} .
$$

Now the resistances of wires are:

$$
\dot{R}_{1}=R\left(1+\frac{I_{2}}{I_{1}} e^{j\left(\alpha_{2}-\alpha_{1}\right)}\right) ; \quad \dot{R}_{2}=R\left(1+\frac{I_{1}}{I_{2}} e^{j\left(\alpha_{1}-\alpha_{2}\right)}\right) .
$$


By virtue of Euler's formula

$$
\begin{aligned}
& \dot{R}_{1}=R+R \frac{I_{2}}{I_{1}} \cos \left(\alpha_{2}-\alpha_{1}\right)+j R \frac{I_{2}}{I_{1}} \sin \left(\alpha_{2}-\alpha_{1}\right) ; \\
& \dot{R}_{2}=R+R \frac{I_{1}}{I_{2}} \cos \left(\alpha_{1}-\alpha_{2}\right)+j R \frac{I_{1}}{I_{2}} \sin \left(\alpha_{1}-\alpha_{2}\right) .
\end{aligned}
$$

Such values of resistances cannot be realized in practice because of the imaginary component. We shall consider them conditional, which is permissible, since, as a result of their parallel connection, we obtain resistance $R$ of the original conductor. Indeed, taking into account (44) we have:

$$
\frac{\dot{R}_{1} \dot{R}_{2}}{\dot{R}_{1}+\dot{R}_{2}}=\frac{R^{2}\left(1+\frac{I_{2}}{I_{1}} e^{j\left(\alpha_{2}-\alpha_{1}\right)}+\frac{I_{1}}{I_{2}} e^{j\left(\alpha_{1}-\alpha_{2}\right)}+1\right)}{R\left(1+\frac{I_{2}}{I_{1}} e^{j\left(\alpha_{2}-\alpha_{1}\right)}+1+\frac{I_{1}}{I_{2}} e^{j\left(\alpha_{1}-\alpha_{1}\right)}\right)}=R .
$$

We can now see that condition (35) holds with non-collinear currents.

We shall verify the possibility of splitting by computing the voltage drops across the first and the second wire separately, and across the original conductor:

$$
\begin{aligned}
& \Delta \dot{U}_{1}^{\prime}=R\left(1+\frac{I_{2}}{I_{1}} e^{j\left(\alpha_{2}-\alpha_{1}\right)}\right) I_{1} e^{j \alpha_{1}}=R I_{1} e^{j \alpha_{1}}+R I_{2} e^{j \alpha_{2}} ; \\
& \Delta \dot{U}_{2}^{\prime}=R\left(1+\frac{I_{1}}{I_{2}} e^{j\left(\alpha_{1}-\alpha_{2}\right)}\right) I_{2} e^{j \alpha_{2}}=R I_{2} e^{j \alpha_{2}}+R I_{1} e^{j \alpha_{1}} ; \\
& \Delta \dot{U}^{\prime}=R \dot{I}=R\left(\dot{I}_{1}+\dot{I}_{2}\right)=R I_{1} e^{j \alpha_{1}}+R I_{2} e^{j \alpha_{2}} .
\end{aligned}
$$

One can see that with non-collinear current vectors condition (36) holds as well, i.e.:

$$
\Delta \dot{U}_{1}^{\prime}=\Delta \dot{U}_{2}^{\prime}=\Delta \dot{U}^{\prime} .
$$

Next, we should determine the active losses. In the first wire these are:

$$
\begin{aligned}
\Delta \dot{P}_{1} & =\Delta \dot{U}_{1}^{\prime} \hat{I}_{1}=\left(R I_{1} e^{j \alpha_{1}}+R I_{2} e^{j \alpha_{2}}\right) I_{1} e^{-j \alpha_{1}}=R I_{1}^{2}+R I_{1} I_{2} e^{j\left(\alpha_{2}-\alpha_{1}\right)}= \\
& =R I_{1}^{2}+R I_{1} I_{2}\left[\cos \left(\alpha_{2}-\alpha_{1}\right)+j \sin \left(\alpha_{2}-\alpha_{1}\right)\right]
\end{aligned}
$$

and in the second wire:

$$
\Delta \dot{P}_{2}=\Delta \dot{U}_{2}^{\prime} \widehat{I}_{2}=\ldots=R I_{2}^{2}+R I_{1} I_{2}\left[\cos \left(\alpha_{1}-\alpha_{2}\right)+j \sin \left(\alpha_{1}-\alpha_{2}\right)\right] .
$$

Their sum is:

$$
\Delta P_{\Sigma}=\Delta P_{1}+\Delta P_{2}=R I_{1}^{2}+2 R I_{1} I_{2} \cos \left(\alpha_{2}-\alpha_{1}\right)+R I_{2}^{2},
$$

since $\cos \left(\alpha_{2}-\alpha_{1}\right)=\cos \left(\alpha_{1}-\alpha_{2}\right)$, and $\sin \left(\alpha_{2}-\alpha_{1}\right)=-\sin \left(\alpha_{1}-\alpha_{2}\right)$. The losses in the paths are complex numbers (not real), while their sum is a real quantity. 
The losses of the total current in the original conductor are:

$$
\begin{gathered}
\Delta P=\Delta \dot{U}\left(\widehat{I}_{1}+\widehat{I}_{2}\right)=\left(R I_{1} e^{j \alpha_{1}}+R I_{2} e^{\alpha_{2}}\right)\left(I_{1} e^{-j \alpha_{1}}+I_{2} e^{-j \alpha_{2}}\right)=\ldots= \\
=R I_{1}{ }^{2}+2 R I_{1} I_{2} \cos \left(\alpha_{2}-\alpha_{1}\right)+R I_{2}{ }^{2} .
\end{gathered}
$$

The sum of losses for non-collinear currents coincides with the losses in the original conductor, which corroborates the legitimacy of conductor splitting. The share of losses for which the supplier pays can be defined as

$$
\begin{aligned}
& \eta_{1}=\frac{\Delta P_{1}}{\Delta P}=\frac{I_{1}^{2}+I_{1} I_{2} \cos \left(\alpha_{2}-\alpha_{1}\right)}{I_{1}^{2}+2 I_{1} I_{2} \cos \left(\alpha_{2}-\alpha_{1}\right)+I_{2}{ }^{2}} \\
& \eta_{2}=\frac{\Delta P_{2}}{\Delta P}=\frac{I_{2}{ }^{2}+I_{1} I_{2} \cos \left(\alpha_{2}-\alpha_{1}\right)}{I_{1}{ }^{2}+2 I_{1} I_{2} \cos \left(\alpha_{2}-\alpha_{1}\right)+I_{2}{ }^{2}} .
\end{aligned}
$$

This allocation is done for two suppliers. When there are more suppliers, the losses of each supplier can be defined separately, with the remaining suppliers merged together. For example, in the case of three PPs it is necessary to select the current of the first PP, merging the second and the third, and determine its share of losses; the same should be performed with the second and the third. This can be done, since the associative law is expressed as

$$
\Delta P_{1}+\Delta P_{\Sigma 1,2}=\Delta P_{1}+\Delta P_{1}+\Delta P_{2}
$$

If the angle between currents $\dot{I}_{1}$ and $\dot{I}_{2}$ is less than $90^{\circ}$, both suppliers should settle their bills; when the angle exceeds $90^{\circ}$ (an imaginary situation since for the directed graphs it is unreal), the sum of losses is smaller than the losses for greater current, the losses of smaller current are negative, and the supplier of greater current pays to the supplier of smaller current. This can easily be verified for the active line resistance $R$. In the first case we assume $I_{1}=I_{2}=0.5 I_{1}$, and in the second $I_{2}=-0.5 I_{1}$.

To determine the losses of a particular supplier in the considered network branch, the current for this supplier should be determined along with other currents. The losses related to a particular consumer and the total losses of a particular PP will be the sum of losses in particular branches. But to calculate them the current shares for given loads should be determined. To achieve a greater accuracy, the line reactances are to be taken into account. As previously stated, there is no physical sense in splitting the reactance of a conductor, however mathematically we can do it. As it was with resistances, the reactances can be conventionally split between the first and the second PPs. Similar to (35) and (36) we can write:

$$
\Delta U_{1}^{\prime \prime}=\Delta U_{2}^{\prime \prime}=X_{1} I_{1}=X_{2} I_{2}=X I=\Delta U^{\prime \prime} ; \quad \Delta U_{1}^{\prime \prime}=\Delta U_{2}^{\prime \prime}=\Delta U^{\prime \prime} .
$$

In such a manner from (32) and (54) we obtain:

$$
X_{1}=X\left(1+\frac{I_{2}}{I_{1}}\right) ; \quad X_{2}=X\left(1+\frac{I_{1}}{I_{2}}\right) .
$$


The analogy with (38) is also held:

$$
\frac{X_{1} X_{2}}{X_{1}+X_{2}}=X
$$

The reactive power losses will be:

$$
\begin{aligned}
\Delta Q_{1} & =X_{1} I_{1}^{2}=X\left(1+\frac{I_{2}}{I_{1}}\right) I_{1}^{2}=X I_{1}^{2}+X I_{1} I_{2} ; \\
\Delta Q_{2} & =X_{2} I_{2}^{2}=X\left(1+\frac{I_{1}}{I_{2}}\right) I_{2}^{2}=X I_{2}^{2}+X I_{2} I_{1} ; \\
\Delta Q_{\Sigma} & =\Delta Q_{1}+\Delta Q_{2}=X I_{1}^{2}+2 X I_{1} I_{2}+X I_{2}^{2}= \\
& =X\left(I_{1}+I_{2}\right)^{2}=\Delta Q
\end{aligned}
$$

The summary reactive power $\Delta Q_{\Sigma}$ is equal to power $\Delta Q$ of the sum of currents. Expressions (56)-(58) show that mathematically such a splitting is correct.

When currents are non-collinear, the reactances are complex quantities:

$$
\begin{aligned}
& \dot{X}_{1}=X\left(1+\frac{I_{2}}{I_{1}} e^{j\left(\alpha_{2}-\alpha_{1}\right)}\right)=X+X \frac{I_{2}}{I_{1}} \cos \left(\alpha_{2}-\alpha_{1}\right)+j X \frac{I_{2}}{I_{1}} \sin \left(\alpha_{2}-\alpha_{1}\right) \\
& \dot{X}_{2}=X\left(1+\frac{I_{1}}{I_{2}} e^{j\left(\alpha_{1}-\alpha_{2}\right)}=X+X \frac{I_{1}}{I_{2}} \cos \left(\alpha_{1}-\alpha_{2}\right)+j X \frac{I_{1}}{I_{2}} \sin \left(\alpha_{1}-\alpha_{2}\right) .\right.
\end{aligned}
$$

Such a presentation is admissible, since coherences (56) and (58) are preserved.

Now we can write the attached impedance for the first and the second source:

$$
\begin{aligned}
\dot{Z}_{1}= & \dot{R}_{1}+j \dot{X}_{1}=R+R \frac{I_{2}}{I_{1}} \cos \left(\alpha_{2}-\alpha_{s}\right)-X \frac{I_{2}}{I_{1}} \sin \left(\alpha_{2}-\alpha_{1}\right)+ \\
& +j\left[X+X \frac{I_{2}}{I_{1}} \cos \left(\alpha_{2}-\alpha_{1}\right)+R \frac{I_{2}}{I_{1}} \sin \left(\alpha_{2}-\alpha_{1}\right)\right] ; \\
\dot{Z}_{2}= & \dot{R}_{2}+j \dot{X}_{2}=R+R \frac{I_{1}}{I_{2}} \cos \left(\alpha_{1}-\alpha_{2}\right)-X \frac{I_{1}}{I_{2}} \sin \left(\alpha_{1}-\alpha_{2}\right)+ \\
& +j\left[X+X \frac{I_{1}}{I_{2}} \cos \left(\alpha_{1}-\alpha_{2}\right)+R \frac{I_{1}}{I_{2}} \sin \left(\alpha_{1}-\alpha_{2}\right)\right] .
\end{aligned}
$$

The flows calculated by a computer program are realistic and should remain unchanged; therefore the active and reactive components of the current are to be calculated separately, based on the active as well as reactive power generation and consumption using the admittance modules. Below, the active component of current is calculated, its reactive component to be calculated in a similar manner. 


\section{LOAD SHEARING BETWEEN POWER PLANTS AND THE ADDRESS COEFFICIENTS}

In Ch. 3, the load allocation was considered when power plants had no common path to a load. The consideration is more complicated when a PP shares a common power line to the load. However the principle remains the same: the admittance of a particular plant should be determined from this plant's buses to the load ones. This means that the cross-section area of the line conductors should be split so that each plant has its share corresponding to its current flowing over the line. This situation is illustrated by Fig. 4. In accordance with Ch. 4, the original scheme can be converted to the circuit diagram of Fig. $4 b$. To each plant a separate part of the cross-section area of a power line is assigned corresponding to the current of this plant. A particular path can be set for each plant to each load. Such a path is shown in Fig. $4 c$ for the first PP. The impedance to load $L_{1}$ is $Z_{G 1 L 1}=Z_{1 G 1}=0$, and the module of admittance $Y_{G 1 L 1}=\infty$; the impedance to load $\mathrm{L}_{1}$ of the second plant is $Z_{G 2 L 1}=Z_{1 \mathrm{G} 2} \neq 0$; the admittance to the load is $Y_{G 2 L 1}=1 / Z_{G 2 L 1}$. Hence, according to (25), the currents of the first and the second PP to load $\left(L_{1}\right)$ are:

$$
\begin{aligned}
& I_{G 1 L 1}=I_{L 1} \frac{Y_{G 1 L 1}}{Y_{G 1 L 1}+Y_{G 2 L 1}}=I_{L 1} ; \\
& I_{G 2 L 1}=I_{L 1} \frac{Y_{G 2 L 1}}{Y_{G 1 L 1}+Y_{G 2 L 1}}=0 .
\end{aligned}
$$

The current in the first line is:

$$
I_{l 1}=I_{G 1 l 1}+I_{G 2 l 1},
$$

where the currents of the first and the second generator are:

$$
I_{G 1 l 1}=I_{1 G 1}-I_{G 1 L 1} ; \quad I_{G 2 l 1}=I_{1 G 2}-I_{G 2 L 1} .
$$

At $Y_{G 1 L 1}=\infty, I_{G 2 L 1}=0$.

The impedances of the first and the second PP in the first line, $\dot{Z}_{G 1 / 1}$ and $\dot{Z}_{G 2 l 1}$, are calculated by $(60)$. The summary impedance of the first and the second plant to the second load are:

$$
\dot{Z}_{G 1 L 2}=\dot{Z}_{G 1 L 1}+\dot{Z}_{G 1 l 1} ; \quad \dot{Z}_{G 2 L 2}=\dot{Z}_{G 2 L 1}+\dot{Z}_{G 2 l 1} .
$$

The corresponding admittance modules are:

$$
Y_{G 1 L 2}=\frac{1}{Z_{G 1 L 2}} ; \quad Y_{G 2 L 2}=\frac{1}{Z_{G 2 L 2}} ; \quad Y_{L 2}=Y_{G 1 L 2}+Y_{G 2 L 2} .
$$

The currents of the first and the second plant to load $L_{2}$ are:

$$
I_{G 1 L 2}=I_{L 2} \frac{Y_{G 1 L 2}}{Y_{L 2}} ; \quad I_{G 2 L 2}=I_{L 2} \frac{Y_{G 2 L 2}}{Y_{L 2}} .
$$


$\mathbf{a}$

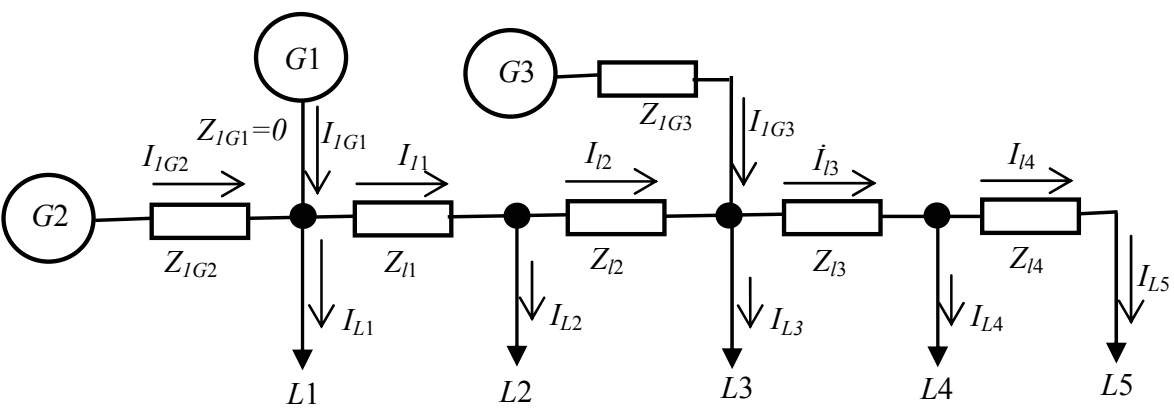

b

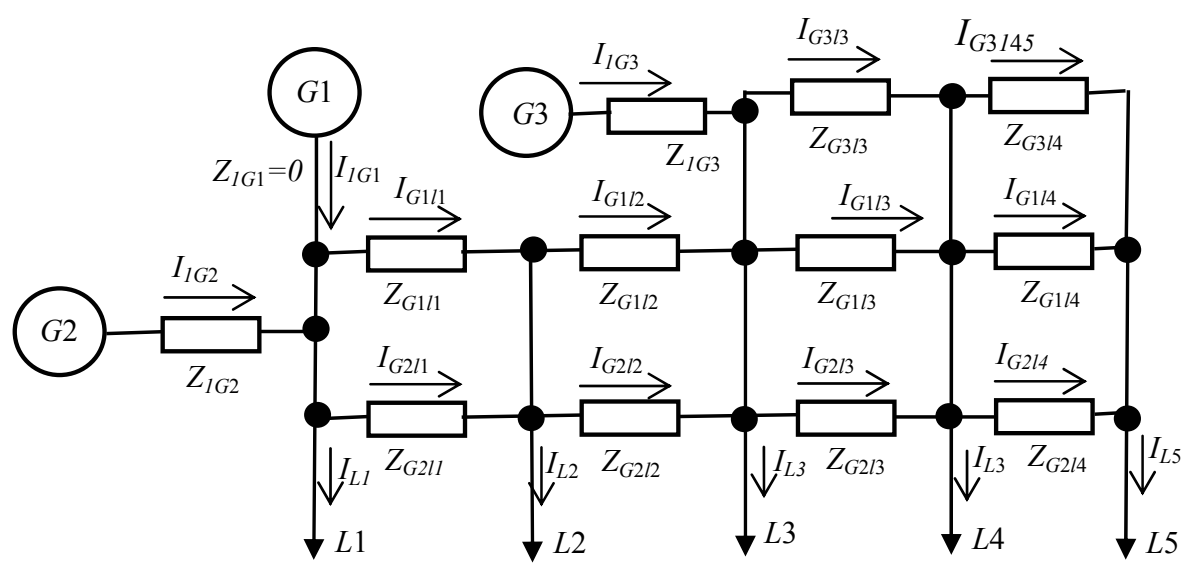

c

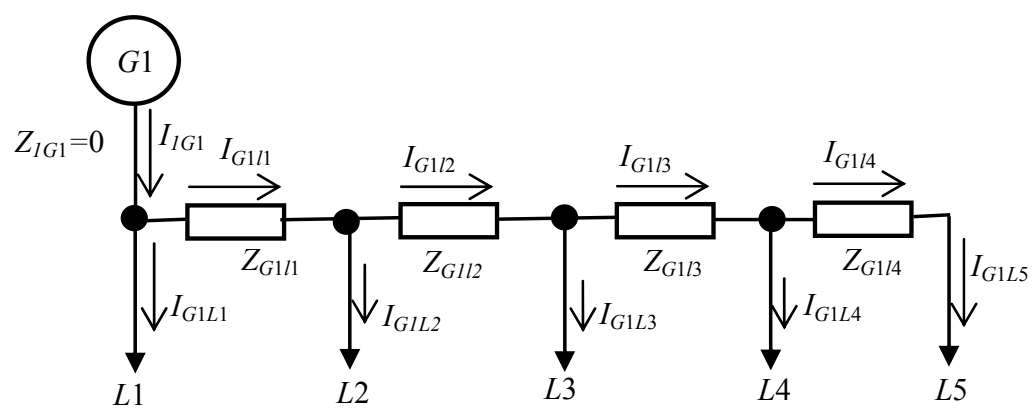

Fig. 4. A network with three suppliers and five loads.

$a$ - original scheme; $b$ - equivalent circuit with individual lines of suppliers;

$c$-assignment of individual line to the first supplier.

The current in the second line is:

$$
I_{l 2}=I_{G 1 l 2}+I_{G 2 l 2},
$$

where the currents of the first and second plant in the second line are:

$$
I_{G 1 l 2}=I_{G 1 l 1}-I_{G 1 L 2} ; I_{G 2 l 2}=I_{G 2 l 1}-I_{G 2 L 2} \text {. }
$$

The admittance of the first and the second plant in line $l_{2}$ is calculated likewise.

When we arrive at the third line, a third plant appears, and by further calculations three currents, three impedances and three admittances are found. 
Proceeding in the same way, the active power can be shared among all loads, observing their distance to these loads. The PP that is the nearest to a load gives out more readily its power to this load. When the plant is close to load, it feeds the load to the maximum possible extent.

The admittances of the $n$-th plant to the $m$-th load $Y_{G n L m}$ being known, the coverage quotients $\beta_{n m}$ can be calculated with the corresponding coverage matrix $\boldsymbol{B}_{G L}$ compiled.

Address coefficients $\alpha_{m n}$ can be determined by the formula:

$$
\alpha_{m n}=\frac{\beta_{n m} P_{L m}}{P_{G n}} .
$$

Further computation can follow the well-known procedure:

$$
\boldsymbol{P}_{L}=\boldsymbol{A}_{L G} \boldsymbol{P}_{G}
$$

If the lines are split in accordance with their currents flowing to each load, the losses for each plant-supplier can be calculated.

In the example, the complex quantity $\dot{Z}$ is arbitrarily transformed to module $Z$ for the admittance module to be determined.

If at some node a line is bifurcated, the current of each source can be determined applying the proportionality principle, taking into account the participation of sources in the initial load coverage on the above stated principles.

The currents of each source in a power line having been calculated, the losses can be determined. The known losses can be added to a given load and the calculations be made anew.

The diversity of possible situations cannot be foreseen, so the described procedure can be perfected, possibly involving other assumptions.

\section{CONCLUSIONS}

1. When solving the problem of load allocation among the energy sources, more or less voluntary assumptions should be made, since, based on the circuit theory alone, the problem cannot be solved.

2. The solution would be more realistic when the current share in a line is allocated based on the summary admittance from energy source to load.

3. The determination of power losses for a particular PP in a line is made corresponding to its current share in this line.

4. The current allocation in power lines should be made separately for the active and the reactive components.

\section{REFERENCES}

1. Danitz, F., Rudnick, H., Zolezzi, J., \& Watts, D. (2002). Use Based Allocation Methods for Payment of Electricity Transmission Systems. Proceedings of Intern. Conf. on Power System Technology. Vol. 2, pp. 907-911.

2. Zolezzi, H.M., \& Rudnick, H. (2003). Consumers Coordination and Cooperation in Transmission Cost Allocation. Proceedings of Power Tech Conf., IEEE, Vol. 3, Bologna.

3. Bialek, J. (Aug. 1997). Topological Generation and Load Distribution Factors for Supplement Charges Allocation in Transmission Open Access. IEEE Transactions on Power Systems, 12 (3), 1185-1193. 
4. Mohd. Wazir Bin Mustafa, \& Hussain Shareef. (Sept., 2005). An Alternative Power Tracing Method for Transmission Open Access, Proceedings of Australian Universities Power Engineering Conf., AUPEC.

5. Kirshen, D, Allan, R, \& Strbak, G. (Febr., 1997). Contribution of Individual Generators to Loads and Flows. IEEE Transactions on Power Systems, 12 (1), 52-60.

6. Jian Yang, \& Max D. Anderson. (1999). Tracing the Flow of Power in Transmission Network for Use-of-Transmission-System Charges and Congestion Management. Proceedings of IEEE Power Eng. Society, (1), 399-405.

7. Ghawghawe, N.D., \& Thakre, K.L. (2007). Modified Method of Computing Generator Participation Factors by Electricity Tracing with Consideration of Load Flow Changes. WSEAS Transactions on Power Systems, 2 (10), 233-238.

8. Kalniņš, M., \& Mahnitko, A. (2004). Elektrostacijas piedalīšanas daļas noteikšana konkrētas slodzes nodrošināšanai. Energétika un elektrotehnika, 11 (4), 47-53.

9. Esposito, G. et al. (2000). Fair allocation of transmission power losses. IEEE Trans. Power Systems, 15 (1), 184-188.

\title{
IESKATS PAR ENERĢIJAS PIEGĀDI SLODZĒM NO ELEKTROSTACIJĀM
}

\author{
J. Survilo, V. Strelkovs \\ Kopsavilku ms
}

Tirgus ekonomikas apstākḷos katrai elektrostacijai jāzina, kādu elektroenerǵijas dalıu tā piegādā konkrētai slodzei un kādi enerǵijas zudumi tai ir, piegādājot šo slodzi. Konkrētam tīklam ir zināmas slodzes un generēta jauda, jauda no bilances mezgla, arī jaudas plūsmas tīkla zaros, jo šos lielumus var aprēķināt pēc datorprogrammām, piemēram, „Mustangs” vai „Power world”. Bet cik no kādas elektrostacijas pienākas jaudas konkrētai slodzei, to programmas nerēķina, jo jaudu no elektrostacijām var pārdalīt starp slodzēm vairākos variantos un no tā elektrotehniskie vienādojumi, kas izmantoti plūsmu aprēķinam, nemainās. Tas norāda uz to, ka šeit nav tīri tehniska risinājuma. Tieši tāpēc šajā jomā ir tik daudz piedāvājumu. Vissvarīgākais starp tiem ir proporcionalitātes princips. Bet šis princips ne vienmēr ir loğisks, tas nesader ar injekcijas mezgla jēdzienu. Bet, ja elektrostacijas piedalī̌sanās daļa slodzes jaudas segšanā nav zināma, tad nav zināma arī šīs elektrostacijas plūsma tīkla zaros, secīgi nav zināmi arī š̄is elektrostacijas zudumi šajā zarā. Rakstā tiek piedāvāts nẹemt vērā pilno vadāmību no spēkstacijas līdz slodzei, kuru baro elektrostacija. Spēkstacijas strāva uz slodzi jārēķina proporcionāli pilnai vadāmībai no spēkstacijas līdz slodzei. Rēķinot pilno vadāmību, nepieciešams izrēķināt nosacītas iesaistīto līniju vadāmības. Nosacītas vadāmības nูem vērā ne tikai šo līniju pilnas vadāmības, bet arī strāvas, kas plūst pa šīm līnijām no citām spēkstacijām. Nosacītas pretestības var būt izrēķinātas ne tikai, kad strāvas līnijā ir kolineārās, bet arī tad, kad šīs strāvas nesakrīt fāzēe pēdējā gadījumā jāṇem vērā leṇkis starp strāvām. Tādā veidā tiek noteikts slodzes segšanas koeficients, kas rāda to slodzes daļu, kas ir segta no attiecīgās spēkstacijas. Kad visi segšanas koeficienti ir aprēḳināti, var noteikt adresācijas koeficientus visām spēkstacijām. Šì metode ḷauj atrast precīzāku attiecīgās spēkstacijas plūsmu konkrētajā līnijā. Attiecīgas spēkstacijas zudumi jārēķina pēc zināmām formulām, pieņemot, ka noteiktā fāzes vada šksērsgriezuma laukuma daḷa pieder izskatāmai spēkstacijai. Šì dą̧a tiek rēķināta, ņemot vērā visas plūsmas šajā līnijā.

29.12.2009 